\title{
RAUDRA AND VIRA RASAS IN THE OATH OF THE VAYUPUTRAS
}

\author{
Prof. Jagdish S. Joshi \\ Mr. Saurabh Vaishnav
}

\begin{abstract}
:
Aesthetic relish or rasa is produced on the part of the reader or observer from observing a work of art. Rasa concerns itself with various emotions, their depiction, inference and transmission through a work of art. Rasa asserts that literature is essentially about life and its emotions. The word rasa is derived from the word 'rasah' which means juice, taste, flavour or relish. The fruit extract is referred to as 'rasa,' which is the essence of it, the ultimate flavour of it. A writer matures as a better writer if the writer can formulate aesthetic experience, and the emotion that such work produces is known as rasa. The Oath of the Vayuputras was published in 2013. It is the final novel of the trilogy. The paper analyses the dominance of Raudra and Vira rasas in the novel.
\end{abstract}

Key words: Rasa, aesthetic, Raudra, Vira, Vayuputras

\section{Introduction:}

The Oath of the Vayuputras is the final novel of the Shiva trilogy written by Amish Tripathi. It was published in 2013. The novel focuses on Shiva's fight against the evil in society. Shiva realises Somras as an evil in society and he wages war against the Kingdom of Meluha where the consumption of Somras is legal and mandatory. Shiva loses his wife Sati due to the underhand tactics of Daksha the 
King of Meluha and the father of Sati. The novel ends with Shiva releasing the divine weapon Pashupatiastra on Meluha and annihilating it.

The present research paper analyses the presence of Raudra and Vira rasas in the novel. The Rasa theory has been propagated by Bharata Muni in his seminal book Natyashastra. Bharata Muni has discussed about the evocation and propagation of eight rasas. Raudra Rasa is one of the important rasa in Natyashastra and the dominant emotion or the sthayibhava in this rasa is krodha or anger. It takes its origin in the raksasas, danavas (evil) and very haughty human beings with a regular battle as its immediate cause. Its outcome is through anger, violation of modesty, abuse, insult, uttering falsehoods, harsh words, animosity, jealousy and kindred ones. The activities connected with raudra rasa are beating, tearing, harassing, chopping off, breaking, piercing, striking hurling missiles, shedding blood, seizing of weapons and similar activities.

The sthayibhavas of raudra rasa, according to Bharata Muni is anger or krodha. The various accompanying states of raudra are correct perception, dynamic energy, panic, resentment, rashness, violence, pride, sweat, trembling, horripilation, stuttering, etc. The presentation of raudra rasa in the dramatic performance is through the anubhavas, such as making the eyes red, perspiring profusely, knitting of the eyebrows, clapping the hands, biting of the lips, throbbing of the cheeks, hitting the palm with the fist etc.

Bharata says in Natyashastra about vira rasa, that vira rasa is properly acted out by firmness, patience, heroism, pride, dynamic energy, bravery, might and profound emotions. Vira rasa is a commitment to the exploration of the power that lies within us. It is the tending of the sacred flame of life with humility that breeds 
confidence. Vira rasa in one of the rasa in the Natyashastra and it deals with the exhibition of energy and enthusiasm with persons of high rank. The Vibhavas or determinants of Vira rasa are composure, absence of infatuation, perseverance, good tactics, humility, valour, power, aggressiveness, mighty influence and other similar things. The presentation of the Vira rasa is through the anubhavas or consequents such as firmness, heroism, patience, readiness to sacrifice, etc.

The vyabhicharibhavas or the transitory states of vira rasa in Natyashastra are fortitude, intellect, pride, impetuosity, ferocity, indignation, recollection, horrification, etc. Vira rasa is produced through enthusiasm, perseverance, absence of grief, absence of surprise and freedom from delusion. The vira rasa should be depicted perfectly through statements such as scolding and censuring the wrong doers, display of bravery, vigour, heroism, enthusiasms, aggressiveness and exploits.

\section{Raudra Rasa in The Oath of the Vayuputras:}

"Shiva's eyes widened, as the rage bubbling under the surface broke through. Screaming at the top of his lungs, he drew a sword and charged" (3). Shiva's uncle Manobhu had gone to meet the Pakrati chief, Yakhya, to discuss peace treaty with him. When Manobhu failed to return, Shiva searched for him and encountered his mutilated read body. Shiva failed to control his emotional rage. He along with his tribe destroyed the Pakrati village to find Yakhya. They rounded up five Pakrati men and asked for the location of Yakhya.

One of the Pakrati man, named Kayna, described the gory details of the death of Manobhu. He mentioned of shoving the intestines and the peace treaty down the 
throat of Manobhu. This made Shiva incensed. Shiva was repulsed to see the overthrowing of morality by murdering a peace messenger. Shiva was abhorred to know the manner in which his innocent and defenceless uncle was murdered by the conspirators.

According to Peter Andersen, "yelling and screaming is a part of physical display of anger" (58). Andersen further states that screaming is associated with anger, one of the most difficult emotions to control. Shiva's incessant screaming signifies Raudra rasa. He was furious at the Pakratis' action of murdering his uncle. Shiva's anger was manifested through his screaming, his charging towards the Pakratis as well as beheading all five Pakratis.

"Veerini held her head in despair. "I made him," said Daksha. "And I will finish him"' (83). Sati had denounced Daksha. Daksha was not able to accept it. Veerini tried to coax her husband to leave all animosity towards Shiva and migrate to Panchvati. Veerini persuaded Daksha by saying that they can live with peace and harmony.

However, Daksha was not able to forget and forgive Shiva. Daksha felt that Shiva created animosity between him and his daughter. Daksha felt that Shiva had brainwashed Sati. Daksha was longing for his beloved daughter Sati, but he blamed Shiva for the conundrum. Daksha's reaction to the coaxing of Veerini reflects Raudra rasa to its extreme.

Trudy Govier explains the act of seeking revenge as:

Seeking revenge is one way to reassert ourselves, to attempt to get relief from the hurt and humiliation of being wronged. If one person or group has 
wronged another, it is common for the victim, the injured party, to feel rage and resentment, leading to a desire to 'get one's own back,' or 'get even.' When we seek revenge, we seek satisfaction by attempting to harm the other (or associated persons) as a retaliatory measure. We expect to feel better if we can somehow express our negative feelings in actions intended to 'get back' at those who have harmed us. (13)

Daksha wanted to reassert himself. He wanted to again have a congenial relationship with his daughter. He felt that Shiva had wronged him by usurping his daughter away from him. As mentioned by Govier, Daksha wanted to 'get back' at Shiva. He vowed that it was him who created Shiva and it will be him who will destroy Shiva. Such actions demonstrate the presence of Raudra rasa. Daksha's furious rage and anger proves the presence of Raudra rasa.

"“'Dammit! He is my husband! How dare you?" . . . Anandmayi turned towards the Naga soldiers standing guard at the door. "My husband is no criminal!"” (197198). Anandmayi's statements, her facial contortions, her body language and her tone of speech all point out that she is furious. Her husband, Parvateshwar had been accused to conspiring against Shiva and being a traitor. Her husband had been ordered by Queen Kali to be captured, chained and imprisoned.

When Anandmayi heard about it, she stormed into the prison and vented out her anger on the soldiers keeping guard on Parvateshwar. Anandmayi knew the devotion that Parvateshwar had for Shiva. She knew that he revered him. She could not accept the treatment meted out to Parvateshwar. She knew Parvateshwar was honest and devoted to Shiva. The situation of watching him handcuffed and bound in chains that Anandmayi cannot tolerate. 
Izard C. E. writes in Human Emotions:

In the innate expression of anger, the muscles of the brow move inward and downward, creating a frown and a foreboding appearance about the eyes, which seem to be fixed in a hard stare toward the object of anger. The nostrils dilate and the wings of the nose flare out. The lips are opened and drawn back in a rectangle-like shape, revealing clinched teeth. Often the face flushes red. (329)

Anandmayi shouted at the soldiers. She said that her husband was no criminal. The pitch and tone of her voice was high, which reflected that she was angry. Also she was not ready to be consoled by, as Ayurvati tried to calm her down. An individual who is emotionally charged up and angry is difficult to be calmed. Her teeth are also clenched along with having a frown on her face. Her body language shows that she is experiencing the emotion of anger at its fullest.

Anandmayi loved her husband, and the thought of him being accused as a traitor propelled her to have full blown anger experience. Anandmayi throughout the novel series has been shown as impulsive and instinctive. Her character traits make her react in anger when she is confronted by the situation where her husband is locked and handcuffed. The primary emotion that is reflected in this scene is of anger. This proves the existence of Raudra rasa in the scene.

"Ganesh clenched his fists, staring at his mother's disfigured face. He gritted his teeth and breathed rapidly, his normally calm eyes blazing. His long nose was stretched out, trembling in anger. His big floppy ears were rigid" (348). All these 
attributes are characteristics of Raudra rasa. Ganesh is furious on looking the scar on the face of his mother.

Adrian Faupel et al., in their book titled Anger management: A Practical Guide note down the following physical signs that a body undergoes when the person is angry. They are, "quicker breathing; heart beating faster; strange sensations in our stomach; beads of sweat or perspiration; tense, tight face, and when really angry, often quite pale (though we may go red in the face in early stages); tense, taut muscles, especially in the legs and arms; pupils often dilated; fidgety, small but quick movements" (35).

The authors substantiate that the physical human body undergoes a transformation while experiencing anger. Various physiological changes are visible when an individual experiences anger. The authors further state that adrenaline and cortisol are the two chemicals that are responsible for the physiological changes in a human body. These chemicals are produced to raise the blood sugar levels and provide energy for the muscles and the brain.

When Ganesh arrived from Lothal, he was asked by Shiva to meet him before Ganesh met his mother. Shiva at that time conditioned both Ganesh and Kartik and made them aware about the injury on the face of Sati. Shiva tried his best to convince them to act passively in front of their mother. On meeting their mother and looking at her face, Kartik successfully controlled his anger and shock, however Ganesh was not able to accept and watch the heinous scar on the face of Sati.

He was furious and mad with rage. The various physiological changes as stated by Adrian Faupel at al. are visible in Ganesh. His fists were clenched, his 
teeth were gritted, his breathing was rapid, his eyes were blazing, his nose was stretched out and his ears became rigid. Ganesh felt it difficult to accept the condition of his mother. He was not able to suppress his love for his mother as instructed by Shiva. He displayed his emotions of anger without any reservation.

All these symptoms point out the presence of Raudra rasa in the section of the novel. Such physiological changes in the body clearly signify the presence of Raudra rasa. The basic emotion of Raudra rasa is anger, and anger is visible on the face of Ganesh. This section of the novel echoes the presence of Raudra rasa.

"“'Did you? Have you looked at her body? "Dada, of course, I have ..." "There are fifty-one wounds on her! I counted them, Kartik! Fifty-one!" "I know . . ." Furious tears were pouring down Ganesh's face. "Those bastards must have continued hacking at her even after she was dead!"' (500). Sati's death had left all immobilized and paralyzed. Everyone wished to exact vengeance on the Meluhans. Ganesh and Kartik were sitting beside the dead body of their mother which was held by Shiva.

Ganesh dreamt of his mother urging him to avenge her death. Ganesh and Kartik were discussing sitting next to each other. Kali, Bhagirath and Gopal too were discussing about the next course of actions. Kartik requested all to set aside their pain and think responsibly. Ganesh was offended by Kartik's statement and he asked Kartik about his mother's death. He rhetorically pointed to Kartik that there were fifty-one wounds on her mother's dead body. Rage and fury was taking over Ganesh as he mentioned that his mother's attackers would have continued hacking Sati's body even after her death. 
Ganesh was traumatized at the death of Sati. While Kartik proposed to think rationally and calmly, Ganesh displayed aggression and fury. His words, his actions and behavior showcased his infuriated state. Bill Cosgrave writes, "When a person experiences anger, (s)he may react in a variety of ways. The most obvious and most common one is to express that anger verbally and/or physically. Such expression of anger may be done in an appropriate or inappropriate manner as will be seen later" (486).

Ganesh was reacting in an aggressive way. His long floppy nose was stiffened. Tears were pouring down Ganesh's face. His whole body movement was stiff and rigid. His breathing was also heavy. Ganesh was furious and not in control of his self. His body language was expressing anger and rage. He was seething with fury. He had counted the number of wounds on his mother's body. He wished and expressed to exact revenge on the murderers of his mother. The scene showcased the presence of Raudra rasa.

\section{Vira Rasa in The Oath of the Vayuputras:}

“"My friends," said Kartik. "Unlike my father, I'm not good with words. So I will keep this short"' (248). Kartik had been assigned the task of fighting the battle of BalAtibul Kund against the forces of Magadh. Shiva had personally requested Kartik to fight the battlefront. Kartik lead the Branga and the Naga soldiers in the battle. As Kartik's army congregated on the battleground of Bal-Atibul, Kartik decided to rally up the army with his speech.

Kartik had already showcased his battle prowess earlier to his army in his exploits against the rhinoceros as well as the battle that he fought singlehandedly. 
His whole army was feeling confident of being led by Kartik. Kartik was aware about the difficulty posed by the upcoming battle. The Magadhan army was huge in number and it would take a mighty effort to defeat them. Kartik was aware of the psychological warfare and hence he decided to address his army before the start of the war.

Kartik kept his speech short and meticulous. He talked about the motivational force behind the Magadhan army which is conquest and glory. He then talked about their motivational force which is to fight for vengeance and retribution. He reminded the Branga as well as the Naga soldiers about the ill effects of Somras on their children and their family. He reminded of how Somras killed and crippled their family members and so the fight was against the Magadhans who had openly used Somras discarding its waste which had spread havoc in the lives of the Brangas and the Nagas.

Kartik was successfully able to arouse and instil the feelings of bravery and valour in his army through his speech. He fuelled their desire for vengeance and retribution through his speech. W. R. Underhill in Communication Quarterly discusses psychological warfare and states, "The term 'psychological warfare' refers to the use of available means of communication in order to weaken the enemy's will to fight and to increase the leading army's resolve to win" (4). Underhill further notes the advantage such a speech can have by stating that a public address before the battle is likely to evoke widespread reactions primarily benefitting the army that is addressed in the speech (6).

Kartik by tactfully implementing a psychological warfare through his speech displayed the characteristics befitting a warrior. His speech was able to instil the 
virtues of bravery and fighting spirit in his army men. His speech had a positive effect on his army as now his army men were more resolute and motivated to fight the Magadhans in the battle. Kartik displayed the features of a fighter, a brave and a confident man, and also displayed his leadership skills through his commanding speech. Such portrayal of characteristics is evidence of the presence of Vira rasa in this part of the novel.

"'It constantly reminds me of my failure. I will not rest till I have set it right and recovered the ground that I lost for my army"' (346). Sati did not want to rest leaving her army. She was brutally wounded the last time she stepped foot on the battlefield. Half of her face was blemished by an ugly scar during her participation in the last battlefield. Sati rejected the suggestion of Ayurvati to perform a cosmetic surgery on her face to bring back her beauty.

Sati however had different plans. Not only she rejected the proposal of a cosmetic surgery, but she also showed her readiness to participate in the next battle. She blamed herself for the loss of the last battle. She felt guilty for it. She decided that she would not stay in a hospital and have a cosmetic surgery performed on her face; rather she would join the battlefield and try to make amends from the last battle for her army.

She also had another reason for her joining the battle. She is a warrior and a leader. She knew that she cannot afford to stay low and cower under her guilt, rather fight by all means necessary. She did not want her soldiers perceive her as a loser and a whiner rather as a leader who displayed grit and determination and also someone who makes active decisions. 


\section{Cremer writes in The Proactive Leader:}

Taking action is necessary for a leader not only because it is a key element in many leadership theories but also because it is an essential ingredient influencing how followers perceive you as a leader. The absence of any decision power and willingness to make a decision invites a host of negative perceptions that can significantly undermine your leadership legitimacy and effectiveness - both in the short- and long term. (11)

Sati was aware that the soldiers might have negative perceptions about her. She knew that she had to take a decision and not just wait for the action to unfurl. She had to be an active participator when the battle ensued. Hence her decision to fight, rejecting her proposal of a cosmetic surgery to help overcome the scar on her face, displays the presence of Vira rasa. Sati was a warrior and she would not her injury and the prospect to be undermined by her soldiers lightly and she showed her readiness to join the next battle. This proves the presence of Vira rasa in this section of the novel.

"Swuth whirled around, stunned. Sati was up on one knee. She was breathing rapidly, forcing some strength into her depilated body. She had dug her sword into the ground and her right hand was on its hilt as she tried to use the leverage to push herself up" (477). After killing Qa'a, Sati was ready for another duel of Aten. This time, Swuth the leader of the Egyptian assassins, stepped forward. The battle between Swuth and Sati was violent and bloody. Swuth fought with all his might and he tried to attack Sati from all sides. Sati was cautious and prepared to defend all attacks by Swuth. 
Swuth kept on attacking her. Sati had already lost her eye, her abdomen which was split and her four fingers from the left hand which were sliced off, committed a mistake that Swuth was waiting for. Swuth brought his sword up in low, brutal jab. The sword went through Sati's abdomen, ripping almost every single vital organ; her intestines, stomach, kidney and liver were slashed through viciously. This paralyzed Sati and her face twisted in agony. She collapsed on the ground and the dark blood began to pool on the ground around her.

But Sati was still not willing to die, lying on the ground. She wanted to die with her head held high. Even though her vital organs were slashed through, Sati with the help of the hilt of the sword, stood up with her right hand. Sati is not willing to succumb. She displayed the characteristics of a warrior. Her spirit had not been broken. She raised herself with all her might. Swuth looked at her with disbelief. He could not believe that an individual who had lost a tremendous amount of blood and most of the vital organs was not giving up and willing to fight.

\section{William Cohen writes in Heroic Leadership:}

You have to be "up front," where the action is. That way you can see what is going right and what is not. You can make critical decisions fast without things having to work their way up and down the chain of command for approval. You can see your people - and they can see you. With you out front there is no question in anyone's mind as to what you want done, and the fact that you are there, on the spot, lets people know just how committed you are to getting your goals accomplished. Your view from the front lets people know that you think what they are doing is important. It lets all who would follow you know that you are ready, willing, and able to share in their hardships, problems, 
successes, and failures in working toward every goal and completing every task. Moreover, being where the action is gives you an opportunity to set the example. Remember that to be a leader, you have to lead — and that means being out in front. (89)

Sati led from the front. She saw that Nandi and her guards were being attacked by the hooded men, but she did not hesitate even for a moment. She gallantly rode on her horse towards the battlefield. She at once jumped in front of Nandi and protected him. She sacrificed her life in order to bide time for Nandi so that he could be saved. And she led from the front. Sati remembered her earlier failure of being unable to save her army when her strategy of using the elephants overturned on her army and she lost significant soldiers in her army. The incident bore a huge mark in Sari and she was ready to wipe the memory of her failure even at the sacrifice of her life.

Sati also by being on the front set an example for others. It showed her commitment towards her army and her dedication to defend the honour of her army. She was rising again and again defiantly against Swuth and even the tactical, trained and barbarian Egyptian assassin was moved to see the integrity and honour of Sati. Her body was ravaged and she was minutes away from dying but this did not stop her from giving up. She rose again and again that made Swuth revere her.

\section{Chögyam Trungpa in the book Smile at Fear writes:}

There's only one way a true warrior can project to others: through personal understanding. Then you can demonstrate to people that their poverty-logic about their lives does not hold truth. Let them wake that way. A genuine 
warrior has a lot of resources within herself, resources that are always there. Although you feel that you've run out of ideas, you're not really running out of anything. You're being alacked by your own cowardice. You can go beyond that and find further resources within yourself. Banks and banks of inspiration unfold constantly. (104)

Sati banked on herself. She had confidence and she was ever resourceful. She did not project cowardice. She projected herself as a powerful and defiant leader. She outshined the Egyptian nemesis as a leader. She displayed her resourcefulness even during desperate times. She had all the qualities of a warrior. During her final moments, Sati displayed the epitome of Vira rasa.

I am guilty. I took the Somras. I followed the Emperor and, through my complacency and silence, was party to everything that conspired to bring this about. If this is Meluha's evil, then it is my evil too. My karma. I will pay my debt to the Neelkanth this day, and pray that it may allow me to be reborn with a little less sin upon my soul. (508)

Shiva decided to release the powerful weapon of mass destruction Pashupatiastra on Devagiri. He decided to annihilate the manufacturing units of Somras and along with it also the people who played a part in the manufacturing of it.

The people who chose to leave Devagiri and not consume Somras were requested by Shiva to leave the city. Bhagirath, Chandraketu and Maatali were supervising the construction of perimeter before the use of Pashupatiastra. Bhagirath was inquisitive about the movement of the people. He saw that there were some 
people who came to the gates, bid their families goodbye and returned to the city. $\mathrm{He}$ was not able to understand the situation.

Bhagirath asked Gopal about the movement of the people. Gopal clarified that some people were willingly staying behind in the city and sacrifice their lives for partaking in the evil. Bhagirath could not believe it. He stopped a woman who had come to the gates and was returning back to her house in the city after bidding her family goodbye. Bhagirath asked the reason for returning back to the city which was going to be destroyed. The woman said that she was following the laws established by Lord Rama.

The woman further said that she followed the Emperor and had consumed Somras despite it was banned by the Neelkanth. The woman was now ready to sacrifice her life due to her partaking in the sins of her land. The woman wished that by sacrificing her life, she would pay a debt to the Neelkanth and lessen her sins from her soul. The woman was not afraid to die because she felt that she committed a sin against the laws of the land. She was a member of the society and hence she felt that she had to accept the fate of the society which was going to be destroyed.

Mark Juergensmeyer writes in:

Martyrdom and Sacrifice in a Time of Terror", "The concept of sacrifice finds its fullest meaning within the context of cosmic war. The sacrificial victim represents the destruction endemic to battle. Sometimes it was God him- or herself who was offered up, or a divinely inspired person such as Jesus or Husain, whose very existence was extraordinary. It was their sacrifice that made them divine. (420) 
The woman's choice to sacrifice her life showed that the woman had the qualities of a warrior. The warrior would take the onus upon oneself for the betterment of the society. The woman did not show the qualities of a coward. She did not run away from the destruction of the city. She had lived her life according to the laws and rules of her society and now that her society was about to be destroyed, the woman chose to stay with her society and sacrifice herself.

The quality of sacrificing herself and clinging to the norms and rules of the society project the woman as possessing the characteristics of a warrior. A warrior would not compensate the ideals and ethics of oneself. The unnamed woman's predisposition point out the presence of vira rasa in the chapter.

\section{Conclusion:}

Throughout the novel, Shiva, Daksha, Anandmayi, Ganesh, etc. display raudra rasa. Shiva's uncle Manobhu had gone to meet the Pakrati chief Yakhya in order to make amends. But when the Pakratis murdered Manobhu and mutilated his dead body, Shiva reflects raudra rasa. Daksha too vows vengeance against Shiva for creating a rift between him and his daughter. He reflects raudra rasa through his actions and dialogue. He wanted to take revenge on Shiva as he believed that Shiva was the main reason for Sati's mistrust towards him.

Anandmayi is livid when her husband Parvateshwar is chained and kept in jail. Her ferocious nature and her actions reflect the presence of raudra rasa. She shouts at the top of her voice at the soldiers who were guarding her imprisoned husband. When Sati is murdered by the Egyptian assassins, Ganesh displays the 
presence of raudra rasa through his dialogue. He reminds Kartik about the number of scars which he had counted.

Sati dominantly reflects the presence of vira rasa. Even though she lost the battle, she reinvigorated and redeemed herself by gallantly fighting against the Egyptian assassins. She lost her eye, her abdomen was ripped apart and she was profusely losing blood. However that did not deter her from displaying the warrior spirit that she possessed. The present research paper analysed the presence of raudra and vira rasas in The Oath of the Vayuputras. 


\section{Works Cited}

Andersen, Peter A. The Complete Idiot's Guide to Body Language. Alpha Books, 2004.

Cohen, William A. Heroic Leadership: Leading with Integrity and Honor. JosseyBass, 2010.

Cosgrave, Bill. "Understanding Anger." The Furrow, vol. 58, no. 9, 2007, pp. 480490. JSTOR, www.jstor.org/stable/27665595. Accessed 2 Apr. 2020.

Cremer, David De. The Proactive Leader: How to overcome Procrastination and be a bold Decision-Maker. Palgrave Macmillan, 2013, pp 11.

Faupel, Adrian, et al. Anger Management: a Practical Guide. Routledge Taylor \& Francis Group, 2018, pp 35.

Govier, Trudy. Forgiveness and Revenge. Routledge, 2002, pp 13.

Izard, Carroll E. Human Emotions. Plenum Press, 1977, pp 329.

Juergensmeyer, Mark. "Martyrdom and Sacrifice in a Time of Terror." Social Research, vol. 75, no. 2, 2008, pp. 417-434. JSTOR, www.jstor.org/stable/40972070. Accessed 2 Apr. 2020.

Tripathi, Amish. The Oath of the Vayuputras. Westland Itd., 2013.

Trungpa, Chögyam. Smile at Fear: Awakening the True Heart of Bravery. Shambhala, 2010.

Underhill, W. R. "The Role of Speech in Psychological Warfare." Communication Quarterly, vol. 9, no. 3, 1961, pp. 4-7. doi:10.1080/01463376109385201.

Prof. Jagdish S. Joshi

Professor and Director

UGC - Human Resource Development Centre (UGC-ASC)

Gujarat University, Ahmedabad

\&

Mr. Saurabh Vaishnav

Assistant Professor

St. Xavier's College (Autonomous), Ahmedabad 